\title{
Presence of phthalate derivatives in the essential oils of a medicinal plant Achillea tenuifolia
}

\author{
Azadeh Manayi ${ }^{1}$, Mahdieh Kurepaz-mahmoodabadi ${ }^{1}$, Ahmad R Gohari ${ }^{1}$, Yousef Ajani ${ }^{2}$ and Soodabeh Saeidnia ${ }^{{ }^{*}}$
}

\begin{abstract}
Background: Phthalate, esters of phthalic acid, are mainly applied as plasticizers and cause several human health and environment hazards. The essential oils of Achillea species have attracted a great concern, since several biological activities have been reported from varieties of these medicinal species. On the other side, due to the problems regarding the waste disposal in developing countries, phthalate derivatives can easily release from waste disposal to the water and soil resulting in probable absorption and accumulation by medicinal and dietary plants. As a matter of fact, although the toxicity of phthalate derivatives in human is well-known, food crops and medicinal plants have been exposing to phthalates that can be detected in their extracts and essential oils. Achillea tenuifolia (Compositea) is one of these herbaceous plants with traditional applications which widely growing in Iran.

Finding: The plant root was subjected to hydro-distillation for $4 \mathrm{~h}$ using Clevenger type apparatus to obtain its essential oil before and after acid treatment. Both of the hydro-distilled essential oils were analysed by GC-MS method resulted in recognition of their constituent. Phthalate contamination as (1, 2-benzenedicarboxylic acid, bis (2-methylpropyl) ester (5.4\%) and phthalic acid (4.5\%), were identified in the first and second extracted oils, respectively.

Conclusion: As a warning, due to the potential role of phthalates to cause reproductive toxicity, disturb of endocrine system and causing cancers, medicinal plants have to be considered through quality control for detection of these compounds.
\end{abstract}

Keywords: Achillea tenuifolia, Compositae, Phthalate contamination, Acid treatment

\section{Findings}

Regarding the recent published articles on probable pollution of medicinal plants and other natural medicines like marine algae to phthalate [1,2], finding a detection and even quantification method for phthalates, which can be accurate, fast and cost effective, is a considerable challenge particularly in standardization of herbal extracts and phytopharmaceuticals.

In fact, phthalates are the esters of phthalic acid and mainly used as plasticizers. They are manufactured by reacting phthalic anhydride with alcohols (ranged from methanol (C1) to tridecyl alcohol (C13)) in both straight and branching chains. Due to the toxicity concerns related to lower molecular weight phthalates (3-6 C), they are now being slowly replaced in the US, Canada, and European Union by high molecular weight phthalates $(>6 \mathrm{C})$. The reason might be

\footnotetext{
* Correspondence: saeidnia_s@tums.ac.ir

${ }^{1}$ Medicinal Plants Research Center, Faculty of Pharmacy, Tehran University of Medical Sciences, P.O. Box 14155-6451, Tehran, Iran

Full list of author information is available at the end of the article
}

behind their higher permanency and durability in nature [2]. It is assumed that six million tonnes plasticizers are consumed every year, of which phthalates used in a large number of products including enteric coated pharmaceutical pills and supplements (as viscosity control agents), gelling agents, film formers, stabilizers, dispersants, lubricants, binders, emulsifying agents, and suspending agents [3]. These compounds interfere with endocrine systems in humans specially sex hormones and thyroids [4]. In addition, induction of inflammation, early puberty in girls, oxidative stress, asthma, and allergic symptoms were reported because of these compounds [5-7]. Literature review showed that these compounds could exhibit toxicity in liver, kidney, lung and testis in both animal and human $[2,5]$. Accumulation of phthalates may occur in a variety of herbal medicines especially those are growing up in water and rivers due to the exposure of plants' roots to the polluted wastewater. Consequent exposure of animals and humans to phthalate by using polluted herbs, crops 
and vegetables is possible, since phthalates accumulate in plants [1].

Achillea tenuifolia is distributed in the north and northwest of Iran with small yellow flowers, woody based and several stems [8]. This plant has been used as traditional herbal remedies against sweating and bleeding along with regulation of menstrual cycle and reduction of heavy bleeding and pain [9]. The previous study revealed that the oil of the plant compromised of several monoterpenes and sesquiterpenes [9-12]. There is also a report on the phytochemical content of the root extract demonstrating the presence of tannins, sterols and terpenoids [13].

Recently, we reported high percentage of phthalate in a medicinal plant, Lythrum salicaria [14]. In continuing our research on detection of phthalate in medicinal and food plants, here we focused on detection of these compounds in the root oil of $A$. tenuifolia.

\section{Methods}

\section{Plant material and isolation of essential oils}

The roots of $A$. tenuifolia were collected from Qazvin province (1500 m above the sea level) in June 2011(No. 1624) deposited at the Herbarium of Institute of Medicinal Plants, Jahade-Daneshgahi (ACECR), Karaj, Iran.

Air-dried roots (200 g) were submitted to hydrodistillation in a Clevenger-type apparatus for $4 \mathrm{~h}$, subsequently, $10 \mathrm{~mL}$ hydrochloric acid (Merck, Darmstadt, Germany) $(1 \mathrm{~N})$ was added to the residue of the root over night at room temperature and hydro-distilled again for $4 \mathrm{~h}$. As a result of acid attendance in the mixture, hydrolysing procedure of glycosidic components was successfully facilitated. The oils after extraction were separately collected in screw capped glass vials and dried over anhydrous sodium sulphate (Merck, Darmstadt, Germany) and stored at $4^{\circ} \mathrm{C}$ until analyses.

\section{GC-MS analysis}

The essential oil was analysed by GC-MS method on a Thermoquest-Finnigan Trace GC-MS instrument (ThermoQuest, Manchester, UK) equipped with a DB-5 fused silica column $(60 \mathrm{~m} \times 0.25 \mathrm{~mm}$ i.d., film thickness $0.25 \mu \mathrm{m})$. The oven temperature was raised from $60^{\circ} \mathrm{C}$ to $250^{\circ} \mathrm{C}$ at a rate of $5^{\circ} \mathrm{C} / \mathrm{min}$ and held for $10 \mathrm{~min}$; transfer line temperature was $250^{\circ} \mathrm{C}$. Helium was used as a carrier gas at a flow rate of $1.1 \mathrm{~mL} / \mathrm{min}$ with a split ratio equal to $1 / 50$. The quadrupole mass spectrometer was scanned over the 35-465 amu with an ionizing voltage of $70 \mathrm{eV}$ and an ionization current of $150 \mu \mathrm{A}$. The compounds were identified by comparison of retention indices (RI, DB-5) with those reported in the literature and libraries [15-23].

\section{Results and discussion}

The hydro-distillation of the root of A. tenuifolia resulted in extraction of the essential oils before and after acidic hydrolysis in extremely scarce amounts of colourless oils. In order to make sure about the sources of phthalate compounds in this study, no plastic container was used all through the procedure, and no solvent was used during extraction process except for hydrochloric acid that was purchased by analytical grade with no phthalate pollution. In addition, the solvents, used for injection of the samples to GC-MS, were injected alone to the chromatograph just before sample injection in order to detect probable contamination peaks. Taking together, any phthalate peaks detected in this study would highly unlikely be originated from storage, extraction and analysis procedure. GC-MS analysis of the volatile oils revealed the presence of 24 and 29 volatile components in the oils before and after acid treatment, representing $95.3 \%$ and $94.2 \%$ of the total oils, respectively (Table 1). Palmitic acid (36.9\%), 5-dodecyldihydro-2(3H)furanone $(14.9 \%)$ and pentadecanoic acid (5.7\%) were detected as the major constituents of the untreated essential oil, while the major volatile aglycones were identified as isovaleric acid (24.9\%), palmitic acid (15.8\%), cyclohexane (13.3\%), cyclohexadecanolide (7.2\%) and 5-dodecyldihydro-2 (3H)-furanone $(6.1 \%)$ in the hydrolysed oil. Chemical structures of the identified compounds are illustrated in the Figure 1. However, in the previous study on the aerial parts of this plant, monoterpenes were characterized as the major constituents of the oil $[5,6]$. Regarding the present results, palmitic acid and 5-dodecyldihydro-2(3H)-furanone were dominant in both volatile oils. The most considerable point found among the identified compounds is the presence of phthalate contaminations (compounds 31 and 32 in Figure 1) in both oils identifying as 1,2-benzenedicarboxylic acid, bis (2-methylpropyl) ester (5.4\%) in the oil before acid treatment and phthalic acid (4.5\%) in the oil after acid treatment. Presence of phthalic acid in the oil after acid treatment probably attributed to the hydrolysis of its derivatives during acid treatment.

Detection of the mentioned compounds in the oils revealed that these contaminations are able to absorb from water and soil into the plant root. The plant, employed in this study, was gathered from a mountainous region near a seasonal river, which was surrounded by lots of disposed plastics and water bottles. Therefore, the source of contamination would most probably be polluted water particularly, regarding the point that we reduced the probable external contamination during storage, extraction and analysis procedure. Actually, these phthalate derivatives are widely used in plastic items, medical and pharmaceutical products, health care products, food containers, toys and paints. It seems that in Iran, the major sources of these compounds might be disposal plastics and chemical factories. Phthalate contaminations have previously been reported from the essential oils of the plants in several studies reported phthalate contaminations in the plants oils [14,24-27]. Exposure to phthalates during pregnancy 
Table 1 Percentage composition of the essential oils obtained from A. tenuifolia root before and after acidic hydrolysis

\begin{tabular}{|c|c|c|c|c|c|}
\hline \multirow[t]{2}{*}{ No. } & \multirow[t]{2}{*}{ Identified compounds } & \multirow[t]{2}{*}{ KI } & \multirow[t]{2}{*}{ RT } & \multicolumn{2}{|c|}{ Percentage (\%) } \\
\hline & & & & Content $^{a}$ & Content $^{\mathrm{b}}$ \\
\hline 1 & Cyclohexane & 752 & 5.12 & - & 13.3 \\
\hline 2 & n-octane & 900 & 6.68 & - & 0.4 \\
\hline 3 & Iso-valeric acid & 976 & 8.15 & - & 24.9 \\
\hline 4 & 2-methyl butanoic acid & 978 & 8.19 & - & 0.6 \\
\hline 5 & n-decane & 1098 & 11.16 & 0.6 & 1.2 \\
\hline 6 & Benzene-acetaldehyde & 1146 & 12.43 & - & 0.2 \\
\hline 7 & Linalool oxide (cis) furanoid & 1176 & 13.3 & - & 0.4 \\
\hline 8 & Linalool oxide (trans) pyranoid & 1191 & 13.73 & - & 0.3 \\
\hline 9 & Camphor & 1245 & 15.23 & 0.3 & - \\
\hline 10 & Terpinene-4-ol & 1273 & 16.15 & 0.5 & - \\
\hline 11 & Alpha-terpineal & 1289 & 16.54 & 0.6 & - \\
\hline 12 & Dodecane & 1297 & 16.8 & - & 0.5 \\
\hline 13 & Eugenol & 1453 & 21.28 & 1 & 2.7 \\
\hline 14 & Methyl eugenol & 1490 & 22.07 & 0.4 & - \\
\hline 15 & n-dodecanol & 1493 & 22.15 & 0.4 & - \\
\hline 16 & n-tetradecane & 1497 & 22.27 & - & 0.3 \\
\hline 17 & Pentadecane & 1597 & 24.81 & - & 0.1 \\
\hline 18 & Dodecanoic acid & 1649 & 26.04 & 2.6 & - \\
\hline 19 & Spatulenol & 1687 & 26.99 & 2 & - \\
\hline 20 & Caryophyllene oxide & 1690 & 27.07 & 2 & - \\
\hline 21 & Hexadecane & 1697 & 27.23 & - & 0.4 \\
\hline 22 & Tetradecanal (myristaldehyde) & 1763 & 27.54 & 3.9 & 1.8 \\
\hline 23 & Dill apiol & 1771 & 28.91 & - & 0.1 \\
\hline 24 & Apiol & 1788 & 29.3 & 0.5 & - \\
\hline 25 & Tetradecanoic acid (myristic acid) & 1842 & 30.95 & 4 & 1.9 \\
\hline 26 & Cyclocolorenone & 1855 & 30.8 & 0.5 & - \\
\hline 27 & Octadecanal & 1895 & 31.3 & - & 0.3 \\
\hline 28 & Hexadecanal & 1897 & 31.7 & 0.3 & 0.4 \\
\hline 29 & Pentadecanoic acid & 1902 & 32.28 & 5.7 & 4.5 \\
\hline 30 & 6,10,14-trimethyl, 2-pentadecanone & 1928 & 32.38 & 0.9 & - \\
\hline $31^{c}$ & Phthalic acid & 1944 & 32.7 & - & 4.5 \\
\hline $32^{c}$ & 1,2-benzenedicarboxylic acid, bis (2-methylpropyl) ester & 1955 & 32.93 & 5.4 & - \\
\hline 33 & Hexadecanoic acid (palmitic acid) & 2027 & 34.32 & 36.6 & 15.8 \\
\hline 34 & 9-octadecanoic acid (oleic acid) & 2048 & 34.38 & 9.7 & - \\
\hline 35 & Cyclohexadecanolide & 2053 & 34.9 & - & 7.2 \\
\hline 36 & Ethyl stearate & 2079 & 35.41 & 0.9 & - \\
\hline 37 & Docosane & 2087 & 35.57 & 0.5 & 0.2 \\
\hline 38 & Ethylhexadecanoate & 2091 & 35.65 & - & 0.4 \\
\hline 39 & Heneicosane & 2145 & 37.72 & - & 0.5 \\
\hline 40 & 5-dodecyldihydro-2(3H)-furanone & 2150 & 37.92 & 14.9 & 6 \\
\hline 41 & Ethyl linoleate & 2177 & 38.95 & 1.3 & 2.5 \\
\hline 42 & Nonadecanal & 2226 & 40.3 & - & 2 \\
\hline 43 & Tricosane & 2322 & 42.63 & - & 0.8 \\
\hline
\end{tabular}


Table 1 Percentage composition of the essential oils obtained from $A$. tenuifolia root before and after acidic hydrolysis (Continued)

\begin{tabular}{llc}
\hline Hemiterpenoids & - & 24.9 \\
Monoterpenes & 2.8 & 3.4 \\
Sesquiterpenes & 4.5 & - \\
Phenylpropanoids & 0.5 & 0.1 \\
$\mathrm{C}_{x} \mathrm{H}_{y}$ & 1.3 & 17.8 \\
$\mathrm{C}_{x} \mathrm{H}_{\mathrm{y}} \mathrm{O}_{z}$ & 86.4 \\
Phthalate contamination & 5.4 & 48 \\
Total & 95.5 & 4.5
\end{tabular}

Kl: Kovats Index on DB-5 with reference to n-alkanes injected after the oil at the same chromatographic conditions, RT: Retention Time, a: values of the percentages before acidic hydrolysis, b: values of percentage after acidic hydrolysis, c: phthalate derivatives contaminations.

produced serious adverse effects like miscarriage, low birth weight, and preterm birth trough induction of inflammation and oxidative stress [6]. Moreover, fetal exposure to phthalate is associated with behavioral and mental ability; for instance in the third trimester of pregnancy they caused neurogical problems in children even until 4-9 years [28]. Although finding such a toxic manmade group of compounds is not a new concern and they are now replaced in the USA, Canada, and European Union by other plasticizers, but there is a complicated situation in developing countries. In fact, U.S. Environmental Protection Agency (EPA) has current management plan that includes the following eight phthalates: dibutyl phthalate (DBP), diisobutyl phthalate (DIBP), butyl benzyl phthalate

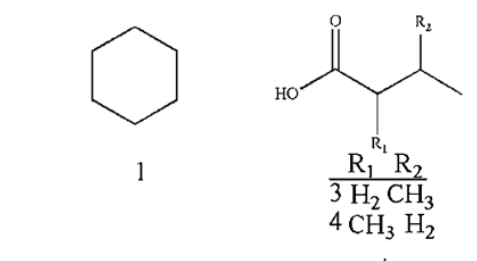<smiles>O=CCc1ccccc1</smiles><smiles>CC1=CCC(C)(C(C)(C)C)CC1</smiles>

$\mathrm{R}_{1} \mathrm{R}_{2}$ $\frac{\mathrm{R}_{1} \mathrm{R}_{2}}{10 \mathrm{OH} \mathrm{H}}$ $11 \mathrm{II} \mathrm{OH}$<smiles>C=C(C)[C@]1(C)CC[C@@H]2O[C@@]2(C)CCC1=C</smiles>

20<smiles>C=CCc1c(N)c(N)c2c(c1N)OCO2</smiles>

\begin{tabular}{ccc}
$\mathrm{R}_{1}$ & $\mathrm{R}_{2}$ & $\mathrm{R}_{3}$ \\
\hline 3 & $\mathrm{H}$ & $\mathrm{OCH}_{3} \mathrm{OCC}$
\end{tabular} $24 \mathrm{OCH}_{3} \mathrm{H} \quad \mathrm{OCH}_{3}$<smiles>C=CC1(C)CCC(C(C)(C)C)O1</smiles>

7<smiles>C/C=C/Cc1ccc(O)c(OC)c1</smiles>

$\frac{\mathrm{R}}{13 \mathrm{H}}$

$14 \mathrm{CH}_{3}$<smiles>CC1=C2C(CC1=O)C(C)CCC1C2C1(C)C</smiles>

26

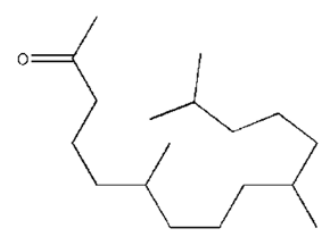

30<smiles>CC(=O)c1ccccc1C=O</smiles>

$\frac{\mathrm{R}}{31 \mathrm{H}}$

32 2-methylbutane<smiles>CCC1CCC(=O)O1</smiles>

35

40

Figure 1 Chemical structures of some identified components and phthalates (31 and 32) from the essential oils of $A$. tenuifolia root. 
(BBP), di-n-pentyl phthalate (DnPP), di(2-ethylhexyl) phthalate (DEHP), di-n-octyl phthalate (DnOP), diisononyl phthalate (DINP), and diisodecyl phthalate (DIDP), of which, BBP, DEHP, and DBP cause the most toxicity to terrestrial organisms, fish, and aquatic invertebrates. Medical device assessments for DEHP have been developed by Food and Drug Administration (FDA), Health Canada Medical Devices Bureau and the European Union Scientific Committee on Medicinal Products and Medical Devices. They concluded that premature infants are the population most highly exposed to phthalates via these uses. Furthermore, The European Commission (2005) banned DEHP, DBP and BBP in all toys and childcare articles. Encouraging industry to move away from phthalates is future plan of EPA [29].

\section{Conclusion}

Finding the phthalate esters in the essential oil of $A$. tenuifolia indicated that these toxic compounds, which have been used as the plasticizers in chemical and pharmaceutical industries, are able to be simply released into the water and soil and accumulate in the plants even in the medicinal species that are growing wildly in mountainous areas surrounded by lots of municipal solid wastes, disposed plastics and water bottles. Derivatives of phthalate esters are able to cause reproductive and developmental toxicity $[1,26]$ regarding their chemical structures. The toxicity of phthalate esters have been well-documented demonstrating that different organisms and tissues of the human and animal bodies could be affected by them including kidney, liver, thyroid and testes $[1,2,30]$. Besides, they could sensitize eye, skin and mucus membranes in human [2]. Taken together, pollution of medicinal plants to phthalate esters in developing countries seems cause a major problem in human health area, which needs more attention in both quality control and standardization of herbal medicines as well as Food and Drug policies or strategies by Ministry of Health.

\section{Competing interests}

The authors declare that they have no competing interests.

\section{Authors' contributions}

AM: GC analysis and drafting the article; MKM: Essential oil extraction and preparation; ARG: Plant gathering and GC/MS analysis; YA: Identification of the plant's scientific name; SS: Conception and designing the study and editing the article; All the authors have read and approved the final version of the article.

\section{Acknowledgements}

This paper is the result of an in-house study and no grants or funds have been received.

\section{Author details}

${ }^{1}$ Medicinal Plants Research Center, Faculty of Pharmacy, Tehran University of Medical Sciences, P.O. Box 14155-6451, Tehran, Iran. ${ }^{2}$ Institute of Medicinal Plants (IMP), Iranian Academic Centre for Education, Culture and Research (ACECR), Karaj, Iran.
Received: 8 October 2014 Accepted: 18 November 2014

Published online: 28 November 2014

\section{References}

1. Saeidnia S, Abdollahi M: Are medicinal plants polluted with phthalates? Daru J Fac Pharm Tehran Univ Med Sci 2013, 21:43.

2. Saeidnia S: Phthalate. In Encyclopedia of Toxicology. Volume 3. 3rd edition. Edited by Wexler P. London: Elsevier Inc., Academic Press; 2014:928-933.

3. Rudel RA, Perovich LJ: Endocrine disrupting chemicals in indoor and outdoor air. Atmos Environ 2009, 43:170-181.

4. Schecter A: Phthalates: human exposure and related health effects. In Dioxins and Health: Including Other Persistent Organic Pollutants and Endocrine Disruptors. 3rd edition. Edited by Meeker JD, Ferguson KK. Hoboken: John Wiley \& Sons, Inc; 2012.

5. The Lowell Center for Sustainable Production at the University of Massachusetts: Phthalates and Their Alternatives: Health and Environmental Concerns, Massachusetts; 2011. http://www.sustainableproduction.org/ downloads/PhthalateAlternatives-January2011.pdf [Last access: Nov 22, 2014]

6. Ferguson KK, Cantonwine DE, Rivera-González LO, Loch-Caruso R, Mukherjee B, Anzalota Del Toro LV, Jiménez-Vélez B, Calafat AM, Ye X, Alshawabkeh AN, Cordero JF, Meeker JD: Urinary phthalate metabolite associations with biomarkers of inflammation and oxidative stress across pregnancy in puerto rico. Environ Sci Technol 2014, 48:7018-7025.

7. Swan $\mathrm{SH}$ : Environmental phthalate exposure in relation to reproductive outcomes and other health endpoints in humans. Environ Res 2008, 108:177-184.

8. Ghahreman A: Flore de I' Irane en couleurs naturelles. Tehran: Institute of Forests and Rangelands (Iran) and Tehran university; 1996.

9. Shafaghat A: Composition and antibacterial activity of the volatile oils from different parts of Achillea tenuifolia Lam. from Iran. J Med Plants 2009, 8:93-98.

10. Aghjani Z, Masoudi S, Rustaiyan A: Composition of the essential oil from flowers of Achillea tenuifolia lam. J Essent Oil Res 2000, 12:723-724.

11. Maffei M, Mucciarelli M, Scannerini S: Essential oils from Achillea species of different geographic origin. Biochem Sys Ecol 1994, 22:679-687.

12. Rahimmalek M, Tabatabaei BES, Etemadi N, Goli SAH, Arzani A, Zeinali H: Essential oil variation among and within six Achillea species transferred from different ecological regions in Iran to the field conditions. Ind Crop Prod 2009, 29:348-355.

13. Manayi A, Mirnezami T, Saeidnia S, Ajani Y: Pharmacognostical evaluation, phytochemical analysis and antioxidant activity of the roots of Achillea tenuifolia LAM. Pharmacogn J 2012, 4:14-19.

14. Manayi A, Saeidnia S, Shekarchi M, Hadjiakhoondi A, Shams Ardekani MR, Khanavi M: Comparative study of the essential oil and hydrolate composition of Lythrum salicaria L. obtained by hydro-distillation and microwave distillation methods. Res J Pharmacogn 2012, 1:37-42.

15. Marques FA, McElfresh JS, Millar JG: Kováts retention indexes of monounsaturated $\mathrm{C} 12, \mathrm{C} 14$, and $\mathrm{C} 16$ alcohols, acetates and aldehydes commonly found in lepidopteran pheromone blends. J Braz Chem SoC 2000, 11:592-599.

16. Alberts AC, Sharp TR, Werner DI, Weldon PJ: Seasonal variation of lipids in femoral gland secretions of male green iguanas (Iguana iguana). J Chem Ecol 1992, 18:703-712.

17. Chen H, Yang Y, Xue J, Wei J, Zhang Z, Chen H: Comparison of compositions and antimicrobial activities of essential oils from chemically stimulated agarwood, wild agarwood and healthy Aquilaria sinensis (Lour.) gilg trees. Molecules (Basel, Switzerland) 2011, 16:4884-4896.

18. Nixon LN, Wong E, Johnson CB, Birch EJ: Nonacidic constituents of volatiles from cooked mutton. J Agri Food Chem 1979, 27:355-359.

19. Yayli N, Gulec C, Ucuncu O, Yasar A, Ulker S, Cuskuncelebi K, Terzioglu S: Composition and antimicrobial activities of volatile components of Minuartia meyeri. Turk J Chem 2006, 30:71-76.

20. MacLeod G, Ames JM: Gas chromatography-mass spectrometry of the volatile components of cooked scorzonera. Phytochemistry 1991, 30:883-888.

21. Valim MF, Rouseff RL, Lin J: Gas chromatographic-olfactometric characterization of aroma compounds in two types of cashew apple nectar. J Agric Food Chem 2003, 51:1010-1015.

22. Beaulieu JC, Grimm CC: Identification of volatile compounds in cantaloupe at various developmental stages using solid phase microextraction. J Agric Food Chem 2001, 49:1345-1352. 
23. Adams RP: Identification of Essential oil Components by gas Chromatography/ Mass Spectorscopy. 4th edn. Carol Stream, III USA: Allured Publishing Corporation; 1995.

24. Srinivasan GV, Sharanappa P, Leela NK, Sadashiva GT, Vijayan KK: Chemical composition and antimicrobial activity of the essential oil of Leea indica (Burm.f.). Merr flowers Nat Prod Radiance 2009, 8:488-493.

25. Muthuchelian K, Ramalakshmi S: Analysis of bioactive constituents from the leaves of Mallotus tetracoccus (Roxb.) Kurz, by gas chromatographymass spectrometry. Int J Pharm Sci Res 2011, 2:1449-1454.

26. Nadaf M, Halimi-khalilabad M, Monfaredi L, Neyestani M: Chemical composition of the essential oil of Stachys lavandulifolia (after flowering) growing wild in darkesh protected area (North Khorassan province Iran). Asian J Plant Sci Res 2011, 1:1-4.

27. Di -Bella G, Saitta M, Pellegrino M, Salvo F, Dugo G: Contamination of Italian citrus essential oils: presence of phthalate esters. J Agric Food Chem 1999, 47:1009-1012.

28. Walter J, Crinnion ND: Toxic effects of the easily avoidable phthalates and parabens. Alt Med Rev 2012, 15:190-196.

29. U.S. Environmental Protection Agency: Phthalates action plan. 2012, file:/// C:/Users/soodabeh/AppData/Local/Temp/ phthalates_actionplan_revised_2012-03-14.pdf [Last accessed: Oct 6, 2014

30. Turner A, Rawling MC: The behaviour of di-(2-ethylhexyl) phthalate in estuaries. Mar Chem 2000, 68:203-217.

\section{Submit your next manuscript to BioMed Central and take full advantage of:}

- Convenient online submission

- Thorough peer review

- No space constraints or color figure charges

- Immediate publication on acceptance

- Inclusion in PubMed, CAS, Scopus and Google Scholar

- Research which is freely available for redistribution

Submit your manuscript at www.biomedcentral.com/submit

() Biomed Central 